Review Article

\title{
Phycoremediation of Synthetic Dyes: An Effective and Eco-Friendly Algal Technology for the Dye Abatement
}

\author{
Abate Ayele (i), Deribe Getachew (D, M. Kamaraj $(D$, and A. Suresh (iD \\ Department of Biotechnology, College of Biological and Chemical Engineering, Addis Ababa Science and Technology University, \\ Addis Ababa, Ethiopia \\ Correspondence should be addressed to M. Kamaraj; drkamarajm@gmail.com
}

Received 23 March 2021; Revised 24 April 2021; Accepted 30 April 2021; Published 19 May 2021

Academic Editor: Rabia Rehman

Copyright (c) 2021 Abate Ayele et al. This is an open access article distributed under the Creative Commons Attribution License, which permits unrestricted use, distribution, and reproduction in any medium, provided the original work is properly cited.

Rapid industrialization leads to serious environmental hazards due to the increase in the release of pollutants into the environment. Industries that use synthetic dyes for different applications are a predominant source for dye contaminants by releasing the dye in wastewater with pretreatment or without treatment directly into the water bodies, making serious water pollution in the environment. Therefore, it is imperative to safeguard the environment from such contaminants and their associated negative impacts. The conventional treatment method that is used to treat dye-contaminated wastewater is generally costly and has a possibility to produce secondary metabolites. Due to the above problems, the biological method is preferable to treat effluent or dye-contaminated wastewater. Phycoremediation is an algae-based eco-friendly dye abatement technique from contaminated environments. This review highlights the phycoremediation of dyes and its underlying mechanisms along with the information on synthetic dyes, classification, hazardous effects, and other major techniques of dye abatement. This review provides a comprehensive insight into several influencing factors such as $\mathrm{pH}$, temperature, contact time, the dose of algae biomass, and agitation speed, as well as functional groups involved in the phycoremediation process.

\section{Introduction}

Dyes are becoming more widely used as a result of their numerous applications in various industries. Dyes are difficult to remove from wastewater due to the aromatic molecular structure that makes them much more stable to light, heat, and oxidizing agents $[1,2]$. A dye is a substance that is used to impart color to a product or material, i.e., paper, leather, textile, rubber, plastic, and cosmetics $[3,4]$. Color added to the product or material creates an attractive appearance and gives added value to an aesthetic for a social reason. Coloring compounds can be made from a natural compound or human made (synthetic). Synthetic dyes are aromatic, water-soluble, and dispersible organic colorants [4]. The use of synthetic dyes significantly increases by the industry such as textile, tannery, paper, printing and dyeing, food, and cosmetics for coloring materials. Dyes help to make the world more beautiful by colored substances; however, they cause serious environmental pollution. In the world, annually, around one million tons of dyes are produced $[5,6]$. A huge amount of synthetic dyes is released into the environment through the textile, pharmaceutical, and chemical industries. From the above three industries, the textile industry is the largest consumer of synthetic dyes.

Synthetic dyes are becoming more common in the textile and dyeing industries due to their ease and cost effectiveness in synthesis, as well as other advantages such as high light stability, firmness against temperature, detergents, and microbes, and color variety, when compared to natural dyes.

During the dyeing process, the main environmental problem associated with the use of dyes is their discharge because the fixation efficiency varies from 60 to $90 \%$ [7]. It is also estimated that about $10-15 \%$ of the dyes are discharged into wastewater during the dyeing process [8]. As a result, it leads to potential pollution in the environment [9]. Many physical and chemical methods have been applied to solve these issues such as adsorption, chemical precipitation, photolysis, chemical oxidation and reduction, 
electrochemical treatment, filtration, coagulation, and chemical flocculation [10-13]. However, these techniques have some disadvantages such as they are expensive, have less decolorization efficiency especially on the synthetic dyes, and are tedious extraction procedures for their organic metabolites. More secondary sludge is generated from these techniques that can cause additional pollution problems as secondary environmental contaminants. Due to these limitations, the bioremediation approach is receiving much attention as the best alternative to physicochemical treatment. Bioremediation is an innovative technology for the treatment of contaminants in which microbes (bacteria, yeast, fungi, and algae) and plants are used to facilitate the degradation or transformation into less harmful types of different toxic chemicals. Phycoremediation is one of the suitable approaches to remove the synthetic dye and maintain the ecosystem using algae, and it has several advantages, including environmentally friendly, high adsorption capacity, quick operation, widely available resources, and low cost.

\section{Overview of Dye}

2.1. Dye and Its Major Classifications. A dye is a coloring material that is used to provide color or to modify existing color for various substances. Dyes have chromophores and auxochromes that are substantively responsible for their color $[14,15]$. Dye is an organic compound that is bright, ionizing, and aromatic. It is usually used in an aqueous solution and displays an affinity for the substrate on which it is applied $[16,17]$. Dyes are categorized as either natural or synthetic depending on their source and their ability to color other substances [18]. Synthetic dyes are recalcitrant compounds that comprise the main residue present in the textile dyeing waste [19]. They are complex aromatic compounds formed by chemical synthesis that provide a wide range of colors [20]. Synthetic dyes are grouped into cationic, nonionic, and anionic types. Under anionic dyes, most demanding water-soluble acids and reactive dyes are shielded. Nonionic dyes, on the contrary, refer to dispersed dyes that are not ionized in an aqueous medium and are listed in Table 1. Among others, anthraquinone-based dyes are the hardest to degrade due to their attached aromatic ring structure.

Color of the dye is a combination effect of chromophores and auxochromes. Chromophores describe the delocalized electron system with double bonds conjugated alternatively; auxochromes refer to electron-withdrawing or electrondonating substituents that enhance color of the chromophores by changing the electron system's overall energy. Some of the essential chromophores include classes of $\mathrm{N}$, $\mathrm{CO}, \mathrm{NO}_{2}$, and quinoids and $\mathrm{NH}_{3}, \mathrm{OH}, \mathrm{SO}_{3} \mathrm{H}$, and $\mathrm{CO}_{2} \mathrm{H}$. The bathochromic effect is shifting adsorption bands to longer wavelengths on a conjugated system of the dye that is advanced by the combination of both chromophores and auxochromes. Also, instead of increasing the chromophores in color processing, auxochromes are responsible for dye solubility and increasing its reactivity to fibers [9]. In anionic and nonionic dyes, the chromophores are mostly azo classes.
During reductive cleavage, the azo group produces toxic amines. Azo-based chromophores contain reactive dyes such as vinyl sulfone, chlorotriazine, trichloropyrimidine, and difluorochloropyrimidine [9].

2.2. Classification of Synthetic Dyes. Dyes are broadly categorized based on (i) chromophoric groups in their chemical structures as azo dyes, anthraquinone dyes, phthalocyanine dyes, etc., (ii) their method of use or application as polyester dyes and cotton reactive dyes, and (iii) their dissociation into an aqueous solution as acidic, basic (cationic), direct reactive (anionic), and disperse/nonionic [21, 22].

Reactive dyes are the only textile dyes designed during the application process to form a covalent bond with the substrate. The reactive dyes offer a wide range of shades of good light fastness and excellent cotton wash fastness. These properties situate this class of dyes at the end of the market quality [23], but massively used by the textile industry. The three most common classes of reactive dyes are azo, anthraquinone, and phthalocyanine [24]. Due to their color intensity and high cellulose reactivity, reactive azo dyes are the most important group of dyes used in the textile industry [25].

Acid dyes are used to color nylon, wool, silk, leather, paper, food, and cosmetics. Acid dyes include chemical groups of azo, anthraquinone, triphenylmethane, azine, xanthene, nitro, and nitroso [26]. Acid dyes are generally bright with a variable stronghold to washing. These dye molecules have great structural variance and include some metal complexes [23].

Azo dyes are the largest group of dyes with a functional group of $\mathrm{N}=\mathrm{N}$ as a chromophore in an aromatic system. Chromophores contain functional groups such as $-\mathrm{N}=\mathrm{N}-$, $-\mathrm{C}=\mathrm{O},-\mathrm{NO}_{2}$, and $\mathrm{O}=\left(\mathrm{C}_{6} \mathrm{H}_{4}\right)=\mathrm{O}$ (quinoid assemblies), and auxochromes contain functional groups such as $-\mathrm{NH}_{3}$, $-\mathrm{COOH},-\mathrm{OH}$, and $-\mathrm{SO}_{3} \mathrm{H}[27,28]$. Azo groups are classified into monazo, disazo, trisazo, tetrakisazo, and polyazo dyes based on the number of azo groups [29].

Triarylmethane dyes are hydrocarbon derivatives that contain two types such as acidic and basic. Triarylmethane acid dyes contain at least two groups of $\mathrm{SO}_{3} \mathrm{H}$ which are used to indicate wool and silk dye fibers. Besides, dyes that comprise only one group of $\mathrm{SO}_{3} \mathrm{H}$ are used as indicators, such as phenolphthalein. On the contrary, basic triarylmethane dyes are massively used in the production of stamping inks, writing, and printing [30].

The sulfonic acid group in anthraquinone dyes is responsible for their water solubility. Mainly, these groups of dyes are used to dye in wool and silk industries due to their ability towards auxiliary binding agents. Food coloring dyes are a subclass of acid dyes that are used to dye protein fibers and certain nylon fibers at high temperatures [31].

Direct dyes are massively used to dye protein fibers and dye synthetic fibers such as nylon and rayon. These dyes lack fast-drying features after applied to fabrics. Basic dyes formed a colored cationic salt when dissolved in water. These cationic salts bind with an anionic substrate. Basic dyes are also known as cationic dyes and are found to be powerful coloring agents for acrylic fibers [8]. 
TABLE 1: Characteristics of synthetic dyes $[9,15,23]$.

\begin{tabular}{|c|c|c|c|c|c|c|c|c|c|c|}
\hline $\begin{array}{l}\text { Synthetic } \\
\text { dyes }\end{array}$ & $\begin{array}{c}\text { General } \\
\text { description }\end{array}$ & Uses & $\begin{array}{l}\text { Ionic } \\
\text { nature }\end{array}$ & $\begin{array}{c}\text { Light } \\
\text { fastness }\end{array}$ & $\begin{array}{l}\text { Washing } \\
\text { fastness }\end{array}$ & $\begin{array}{c}\text { Hot } \\
\text { pressing } \\
\text { fastness }\end{array}$ & $\begin{array}{c}\text { Dry } \\
\text { cleaning } \\
\text { fastness }\end{array}$ & $\begin{array}{l}\text { Seawater } \\
\text { fastness }\end{array}$ & Solubility & $\begin{array}{c}\text { Application } \\
\mathrm{pH}\end{array}$ \\
\hline Acid dye & $\begin{array}{l}\text { Originated } \\
\text { from basic dye } \\
\text { acidification; } \\
\text { complete color } \\
\text { range }\end{array}$ & $\begin{array}{l}\text { Primarily } \\
\text { for wool } \\
\text { and silk; } \\
\text { also, } \\
\text { acetate, } \\
\text { acrylic, and } \\
\text { nylon }\end{array}$ & Anionic & $\begin{array}{l}\text { Very } \\
\text { good }\end{array}$ & Poor & $\begin{array}{c}\text { Not } \\
\text { affected }\end{array}$ & Good & Fair & $\begin{array}{l}\text { Soluble in } \\
\text { water }\end{array}$ & $4-5$ \\
\hline Basic dye & $\begin{array}{l}\text { First synthetic } \\
\text { dye (1856), first } \\
\text { coal tar dye }\end{array}$ & $\begin{array}{l}\text { Primarily } \\
\text { for wool, } \\
\text { silk, nylon, } \\
\text { and cotton }\end{array}$ & Cationic & Poor & Poor & $\begin{array}{c}\text { Not } \\
\text { affected }\end{array}$ & $\begin{array}{l}\text { Mostly } \\
\text { poor }\end{array}$ & $\begin{array}{l}\text { Very } \\
\text { poor }\end{array}$ & Soluble & $5-6$ \\
\hline Direct dye & $\begin{array}{l}\text { Dyes cellulosic } \\
\text { fabrics directly; } \\
\text { some dye wool } \\
\text { and silk }\end{array}$ & $\begin{array}{l}\text { Primarily } \\
\text { for } \\
\text { cellulosic } \\
\text { fabrics }\end{array}$ & Anionic & $\begin{array}{l}\text { Good to } \\
\text { excellent }\end{array}$ & Poor & Good & Good & $\begin{array}{l}\text { Poor to } \\
\text { good }\end{array}$ & $\begin{array}{l}\text { Depends } \\
\text { on the } \\
\text { types of } \\
\text { direct dyes }\end{array}$ & 7 \\
\hline $\begin{array}{l}\text { Disperse } \\
\text { dye }\end{array}$ & $\begin{array}{l}\text { Developed for } \\
\text { acetate }\end{array}$ & $\begin{array}{c}\text { Primarily } \\
\text { for acetate, } \\
\text { also, } \\
\text { polyester, } \\
\text { nylon, and } \\
\text { cellulose } \\
\text { fibers }\end{array}$ & Nonionic & $\begin{array}{c}\text { Fair to } \\
\text { excellent }\end{array}$ & $\begin{array}{l}\text { Fair to } \\
\text { good }\end{array}$ & $\begin{array}{l}\text { Some } \\
\text { color } \\
\text { change is } \\
\text { possible }\end{array}$ & Good & Good & $\begin{array}{l}\text { Slightly } \\
\text { soluble in } \\
\text { water }\end{array}$ & $4-5$ \\
\hline $\begin{array}{l}\text { Reactive } \\
\text { dye }\end{array}$ & $\begin{array}{l}\text { Forms a } \\
\text { covalent bond } \\
\text { with the fiber }\end{array}$ & $\begin{array}{l}\text { Primarily } \\
\text { for cotton } \\
\text { apparel }\end{array}$ & Anionic & $\begin{array}{l}\text { Very } \\
\text { good }\end{array}$ & Good & $\begin{array}{c}\text { Not } \\
\text { affected }\end{array}$ & Good & Good & $\begin{array}{l}\text { Depends } \\
\text { on the } \\
\text { types of } \\
\text { reactive } \\
\text { dyes }\end{array}$ & $11-13$ \\
\hline Sulfur dye & $\begin{array}{l}\text { Insoluble in } \\
\text { water, } \\
\text { complete } \\
\text { shade range }\end{array}$ & $\begin{array}{l}\text { Used for } \\
\text { linen, } \\
\text { cotton, and } \\
\text { jute }\end{array}$ & Nonionic & $\begin{array}{l}\text { Poor to } \\
\text { fair }\end{array}$ & $\begin{array}{l}\text { Poor to } \\
\text { good }\end{array}$ & Good & Good & Good & Insoluble & $10-11$ \\
\hline Vat dye & $\begin{array}{c}\text { Synthetic } \\
\text { indigo original }\end{array}$ & $\begin{array}{l}\text { Used for } \\
\text { cotton and } \\
\text { wool }\end{array}$ & Nonionic & Excellent & Good & Good & Good & Good & $\begin{array}{l}\text { Insoluble, } \\
\text { soluble } \\
\text { leuco salts }\end{array}$ & $12-13$ \\
\hline
\end{tabular}

Disperse dyes are water-insoluble nonionic dyes that are commonly used on polyester, nylon, cellulose, and acrylic fibers. They encompass several groups such as azo, anthraquinone, styryl, nitro, and benzodifuranone. The dyes used for plastics, gasoline, lubricants, oils, and waxes are solvent soluble. These dyes are principally azo and anthraquinone chemical classes. The dyes used for coloring cotton, rayon, silk, leather, paper, and wood are called sulfur dyes. Vat dyes are insoluble in water and used to dye cellulosic fibers. The main chemical groups of these dyes are anthraquinone and indigoids [8].

2.3. Hazardous Effects of Synthetic Dyes. The effluent discharged from the dyeing industries is the major cause of water pollution because it contains a huge volume of dyes. The high concentration of dyes in water bodies blocks sunlight and reduces the oxygenation potential of receiving water, affecting aquatic biodiversity and photosynthesis. Blue, green, or brown color of watercourses is accepted somehow by the public, but red and purple colors in water bodies receive people's concern [32]. The natural pigment used for coloring textile fades easily when it is exposed to sunlight, heat, and water. Approximately $15 \%$ of textile dyes are lost and released into water during the dyeing process. This effluent eventually triggers issues such as mutagenic, carcinogenic, and toxic effects [8]. Synthetic dyes pose widespread health hazards by their nature or the nondegradable byproducts which are produced with the reaction of other chemicals [28].

The industrial effluents containing dyes affect the growth of microorganisms and photosynthetic activities of aquatic flora by reducing light penetration in receiving water bodies. Moreover, discharged dyes reduce the amount of dissolved oxygen in water by forming a thin layer on the surface of the receiving water body. Furthermore, this kind of effluent increases the chemical oxygen demand (COD) which is an indication of high-level pollution [33]. Many of the dyes are carcinogenic and pose a serious hazard to aquatic living organisms such as damage to the liver, gills, intestine, and gonads and destroy aquatic communities in the ecosystem (Figure 1) [35]. Direct use of untreated dyeing effluents for irrigation has serious environmental consequences, such as reduced soil fertility, seed germination, chlorophyll, and protein content in plants [8]. 


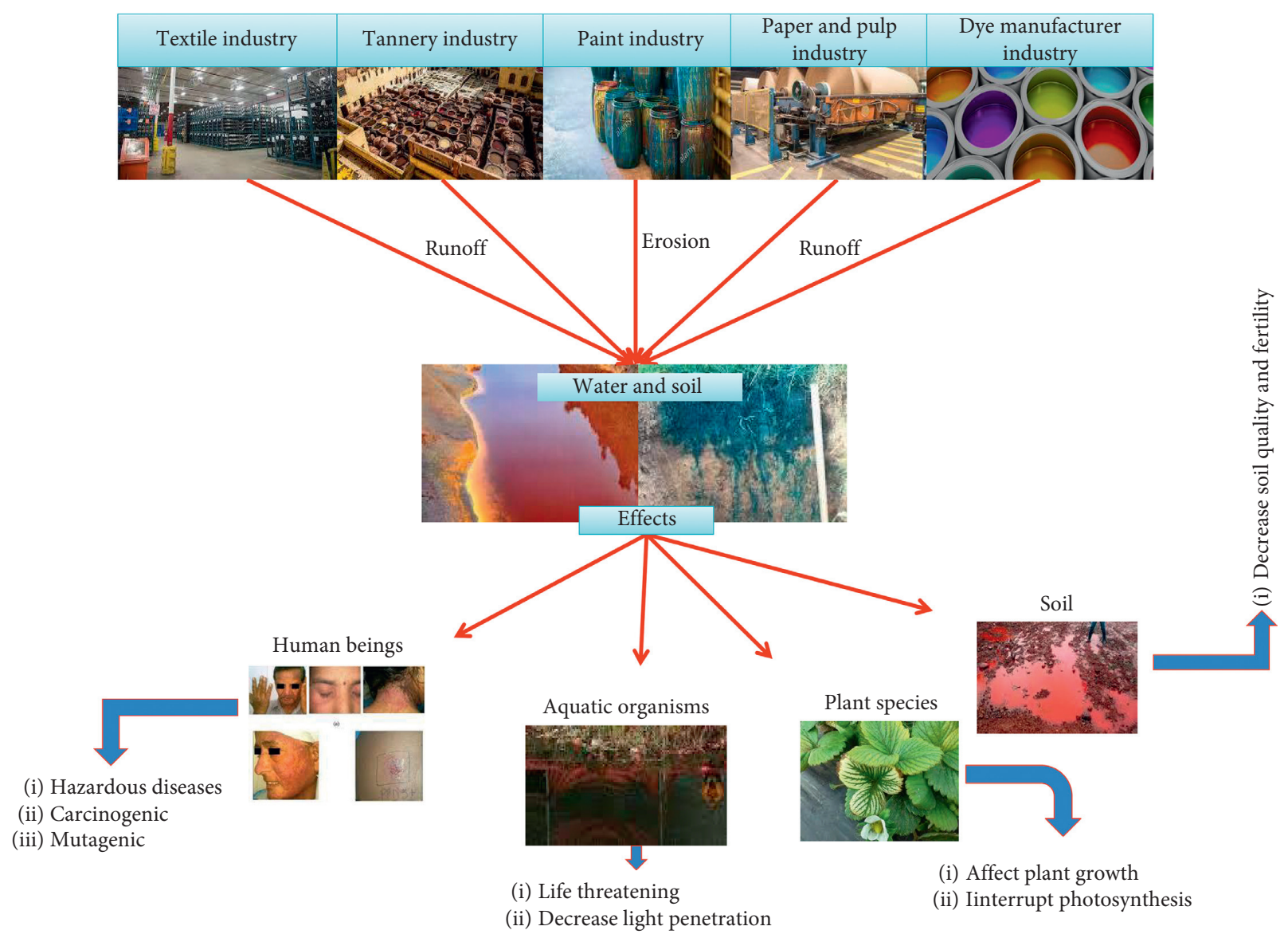

Figure 1: The hazardous effects of synthetic dyes on the environment from different industries [34].

Azo dyes can cause multiple health issues to humans such as skin irritation, chemosis, contact dermatitis, exophthalmos, lacrimation, rhabdomyolysis, permanent blindness, vomiting gastritis, acute tubular necrosis supervene, hypertension, vertigo, and, upon ingestion, edema of the neck, face, tongue, pharynx, and larynx along with respiratory distress [6]. Some dyes cause bladder cancer, splenic sarcomas, hepatocarcinoma, and nuclear abnormalities; in laboratory animals, some dyes cause splenic sarcomas, hepatocarcinoma, and nuclear abnormalities [36]. Through the chemical process, the dyes undertake alteration in the chemical structure resulting in the formation of new xenobiotic compounds that have a great impact on the environment. Additionally, they can also cause skin irritation, allergy, cancer, neurobehavioral disorders, autoimmune diseases, and other human health disorders such as nausea, vomiting, and paralysis and cause severe damages to the liver, kidney, reproductive system, brain, and central nervous system $[21,37,38]$. Some dyes with monoazo or anthraquinone structures have been found to cause hypersensitivity reactions, such as skin irritation or dermatitis [39].

\section{Methods for Synthetic Dye Abatement}

Different conventional technologies such as chemical, physicochemical, and biological methods which are used to treat wastewater contaminated with dyes are summarized in Table 2.

3.1. Conventional Technologies. Conventionally, several physical and chemical methods including ultrafiltration, adsorption, flocculation, coagulation, ozonation, advanced oxidation processes, photocatalytic oxidation, Fenton process, and chemical and electrochemical coagulation were applied for the removal of color [22]. All the aforementioned methods have limitations such as incomplete removal of dyes from the environments, sludge production, short half-life $(20 \mathrm{~min})$ of $\mathrm{O}_{3}$, formation of byproducts, the release of aromatic amines, high cost of electricity, very expensive, ineffective against dispersing and vat dyes, and the repetitive or frequent usage of chemicals leads to secondary pollution problems $[9,40]$. Hence, an alternative technique is needed for the abatement of synthetic dyes. 
TABLe 2: Methods of synthetic dye biodegradation and decolorization [32, 41, 55].

Physical method

Adsorption

Irradiation

Refers to a process where a substance or material is concentrated at a solid surface from its liquid of the gaseous surrounding.

Involves the use of radiations usually obtained from monochromatic UV lamps working under $253.7 \mathrm{~nm}$. It is a simple and effective technique for removing a wide variety of organic contaminants and disinfecting harmful microorganisms.

Microfiltration: it is mostly employed for the treatment of dye baths containing pigment dyes.

Ultrafiltration: this technique can remove polluting substances such as dyes only $31-76 \%$ but can be used to eliminate macromolecules and particles.

Filtration processes

Nanofiltration: it is employed for the treatment of colored effluents from the textile industry mostly in a combination of adsorption and nanofiltration as NF modules are very sensitive to fouling by colloidal materials and macromolecules.

Reverse osmosis This technique is used to eliminate hydrolyzed reactive dyes, most types of ionic compounds, and chemical auxiliaries in a single step.

Chemical method

Electrochemical This process is very simple and is based on applying an electric current to wastewater by using sacrificial iron electrodes to produce ferrous hydroxide.

Oxidation by ozonation is a technology initially used in the 1970s, and it is carried out by ozone generated from oxygen.

Chemical oxidation is the conversion of pollutants by chemical oxidizing agents (such as chlorine, ozone, Fenton reagents, UV/peroxide, and UV/ozone).

Oxidation with sodium hypochlorite: in this treatment, azo bond cleavage is initiated and accelerated by the attack of the dye molecule by $\mathrm{Cl}^{+}$at the amino group.

Oxidative processes The oxidation processes with hydrogen peroxide $\left(\mathrm{H}^{2} \mathrm{O}^{2}\right)$ can be used as wastewater treatment in two systems: $(1)$ homogenous systems based on using visible or ultraviolet light, soluble catalysts such as Fenton reagents which are strong oxidants compared to $\mathrm{H}_{2} \mathrm{O}_{2}$ and other chemical activators such as ozone and peroxidase. (2) Heterogenous systems based on using semiconductors, zeolites, and clays with or without ultraviolet light.

Photochemical oxidation: the UV treatment of dye-containing wastewater in the presence of $\mathrm{H}_{2} \mathrm{O}_{2}$ can break down the dye molecules into smaller organic molecules or even ultimate products such as $\mathrm{CO}_{2}$ and $\mathrm{H}_{2} \mathrm{O}$ and other inorganic oxides.

Coagulation Coagulation of dyes and other auxiliaries in textile effluents has been successfully done by aluminum, iron slats, organic polymer, flocculants, etc.

Electrocoagulation is an advanced electrochemical treatment for dye and color removal. It involves processes such as

Electrocoagulation electrolytic reactions at electrodes, coagulation in the aqueous effluent and adsorption of soluble pollutants on coagulants, and, finally, their removal by sedimentation

Biological method

Aerobic biological treatment: use bacteria and oxygen (from injected air) to remove dissolved organic load (COD/ BOD) from dye-containing wastewater. The process is controlled by oxygen sensors in the activated sludge (aeration tank), and residual bacteria (waste activated sludge) can be separated in various ways.

Bacterial

Anaerobic biological treatment: anaerobic biodegradation of water-soluble dyes including azo dyes is mainly reported to take place by a redox reaction with hydrogen leading to the formation of methane, carbon dioxide, hydrogen sulfide, and other gaseous compounds and releasing electrons.

Fungal Fungal organisms can decolorize a wide range of dyes.

Microalgal

Enzymatic

Algae are capable of decolorizing colored wastewater through mechanisms of enzymatic pathways as well as adsorption on algal biomass.

The enzyme that is produced from microbes and plants is used to degrade or decolorize dyes.

3.2. Biological Treatment Methods. The biological method (bioremediation) is considered the best alternative over conventional physicochemical treatment due to its potential advantages of being inexpensive and nonhazardous. Bioremediation (using microbes) is a pollution control technology where the biological systems are used to drive the degradation or transformation of various toxic chemicals into less harmful forms. Biological treatment methods are eco-friendly methods that are gaining importance in today's scenario. Microorganisms such as bacteria, fungi, algae, yeast, and their enzymes can be successfully utilized to remove color of a wide range of dyes through anaerobic, aerobic, sequential anaerobic-aerobic treatment, and biosorption processes [41-43].
3.3. Phycoremediation. Phycoremediation means the use of macroalgae, microalgae, and cyanobacteria for the removal or biotransformation of contaminants, containing nutrients, synthetic dyes, heavy metals, and xenobiotics from dyecontaminated wastewater and $\mathrm{CO}_{2}$ from waste air (for environmental cleanup) [21, 44]. Removal of nutrients from wastewater, acidic and metal wastewater treatment, degradation, transformation of recalcitrant compounds, and toxic compound detection by using algal-based biosensors are some of the key applications of phycoremediation [45]. Besides, abatement of synthetic dyes by algal biomass possesses advantages such as eco-friendly, high adsorption efficiency, fast process, widely available resources, and low cost [46]. 


\section{Algae}

Algae are derived from the Greek word "alga" which means "phyco." These organisms are heterogeneous, predominantly eukaryotic, and aquatic organisms that differ from microscopic cells to highly differentiated plants. Algae are categorized as either aquatic or freshwater plants which have very high carbon trapping and photosynthetic efficiencies when compared to terrestrial plants [47]. Algae are classified as "thallophytes" or plants that lack roots, stems, and leaves. Chlorophyll is the dominant photosynthetic pigment in these species. On the contrary, they lack a sterile covering of cells around the reproductive cells. The green algae are dispersed in many regions of the world, from being airborne or subaerial to being terrestrial or aquatic, either in freshwater or marine habitats [48]. Algae include macroalgae and microalgae, and many are eukaryotic organisms. Due to this, they have the properties such as those with cells displaying a high degree of internal organization, including a membranebound nucleus containing the genetic material and several other internal parts, organelles that are also surrounded by membranes. On the contrary, the term also consists of cyanobacteria or blue-green algae, which are prokaryotic (those cells that lack a distinct nucleus) [47]. Algae can play an important role in the removal of azo dyes and aromatic amines in stabilization ponds [49]. The dye abatement efficiency of algae is varied based on the dyes' molecular structure and the algae species used for the process [50]. Algae accumulate colored water during their growth and potentially decolorize dye-contaminated wastewater. The resulting biomass is being processed further for the production of bioenergy and algal-based bioproducts [51]. The selected algae used for the abatement of various synthetic dyes are listed in Table 3.

4.1. Microalgae. As the name specifies, these are microscopic algae and can be motile or nonmotile depending on the presence of the flagella. Microalgae are unicellular and photosynthetic microorganisms, usually in the size range of $1-400 \mu \mathrm{m}$, and visible by using a microscope [37, 75]. In terms of biomass, microalgae are one of the largest primary producers and responsible for at least $32 \%$ of global photosynthesis and oxygen production as well as the best known $\mathrm{CO}_{2}$ sequestration [76, 77].

4.2. Macroalgae. Macroalgae are multicellular organisms and are generally seen without the aid of a microscope. Seaweeds, also known as macroalgae, are macroscopic multicellular algae with defined tissues and specialized cells. Macroalgae have cell types that are similar to those of terrestrial vascular plants. Furthermore, the macroalgae may be either marine or freshwater [47, 78]. Macroalgae can accumulate heavy metals, synthetic dyes, and other contaminants reaching concentrations that are thousands of times higher than the corresponding concentrations in seawater. Furthermore, algae fulfill the criteria for bioindicators as they are widely distributed. The microalgae have unique features such as suitable size for high accumulation of metals, easy to identify, and collection and recovery are simple. Macroalgae are grouped into three such as red (Rhodophyta), brown (Phaeophyceae), and green (Chlorophyta) [79]. Macroalgae composition differs based on the species variety. In red algae, galactose-based polyglucans such as agar and carrageenan are majorly observed. The kind of algae that encompass alginate and a large amount of laminarin is called brown algae, whereas green algae principally contain starch and cellulose $[80,81]$.

\section{Factors Affecting the Abatement of Synthetic Dyes by Algae}

The molecular structure and microbial activity are influenced by the culture condition that is necessary for effective abatement of dyes. The algae efficiency of biosorption can be affected by optimizing the operating conditions such as $\mathrm{pH}$, temperature, biosorbent dosage, and agitation [82].

5.1. Effect of $p H . \mathrm{pH}$ is one of the most important parameters that affects the biosorption efficiency of algae [83]. Besides this, it also affects color and the solubility of some dyes. The interface between sorbate and biosorbent is affected by $\mathrm{pH}$ of an aqueous solution. The biosorbent surface has numerous functional groups such as carboxyl, hydroxyl, amino, and phosphates. As a consequence of this, the net charge of biosorbent is dependent on $\mathrm{pH}$. If $\mathrm{pH}$ decreased, the biosorbent surface had more positively charged sites, which were favorable to the adsorption of dye anions due to the electrostatic attraction [84]. At lower and higher $\mathrm{pH}$, the biosorbent surface becomes net positive charge and net negative charge, respectively. Therefore, at lower $\mathrm{pH}$, the biosorbent surface binds with anionic dyes, and also at higher $\mathrm{pH}$, the biosorbent surface is attached with cationic dyes [85]. Aravindhan et al. [86] observed that uptake of Sandocryl Golden Yellow C-2G by green seaweed Caulerpa scalpelliformis increases from 17 to $27 \mathrm{mg} / \mathrm{g}$ with an increase in $\mathrm{pH}$ from 3.0 to 8.0. Initial $\mathrm{pH}$ of the solution appreciably influences the biosorption of dyes due to a change in the surface properties of the adsorbent [87].

5.2. Effect of Temperature. Temperature plays a great role in the biodegradation of dyes. The viscosity of the solution containing the dyes decreased with an increase in temperature. The amount of adsorbed dye decreased with increasing temperature, indicating the exothermic nature of the biosorption process [70]. The decrease in the efficiency of the adsorption due to temperature increases can be dedicated to changes in active sites of the adsorbent and also the tendency of the adsorbed material to get away from the active sites into the aqueous solution [72]. Aravindhan et al.'s results [86] illustrated that the sorption capacity uptake of Sandocryl Golden Yellow C-2G by green seaweed Caulerpa scalpelliformis decreased from 28 to $23 \mathrm{mg} / \mathrm{g}$ with a temperature increase from 20 to $60^{\circ} \mathrm{C}$. 
TABLE 3: Abatement of various synthetic dyes by algae.

\begin{tabular}{|c|c|c|c|c|}
\hline Algae & Synthetic dyes & $\begin{array}{l}\text { Experimental conditions: initial dye conc. }(\mathrm{mg} / \mathrm{L}) \text {, } \\
\mathrm{pH} \text {, time }(\mathrm{hr}) \text {, temp }\left({ }^{\circ} \mathrm{C}\right) \text {, biomass }(\mathrm{g} / \mathrm{L})\end{array}$ & $\begin{array}{c}\% \\
\text { removal }\end{array}$ & References \\
\hline Chlorella vulgaris & Aniline blue & $25,-,-, 264,-,-$ & 58 & {$[52]$} \\
\hline Gonium sp. & Reactive Blue 220 & $-, 8,336,-,-$ & 84.2 & {$[53]$} \\
\hline Gracilaria verrucosa & $\begin{array}{l}\text { Phenoxyalkanoic acid } \\
\text { herbicide } 2,4-\mathrm{D}\end{array}$ &,,,,----- & 47 & {$[54]$} \\
\hline Haematococcus sp. & Malachite green & $100,-,-,-, 1$ & 67 & {$[55]$} \\
\hline \multirow{2}{*}{ Oscillatoria sp. } & Blue dye & $-, 10,336,-, 3$ & 76.48 & \multirow{4}{*}[1]{} \\
\hline & Red dye & $-, 10,336,-, 3$ & 62.63 & \\
\hline \multirow{2}{*}{ Spirogyra sp. } & Blue dye & $-, 10,336,-, 3$ & 78.29 & \\
\hline & Red dye & $-, 10,336,-, 3$ & 64.21 & \\
\hline Scenedesmus bijuga & Monoazo and diazo & $-,-, 48,25,-$ & 68 & {$[31]$} \\
\hline Vaucheria sp. & Malachite green & $-, 8.5,17.5,-,-$ & 85.9 & {$[25]$} \\
\hline Coelastrella sp. & Rhodamine B & $100,8,480,30,-$ & 80 & {$[56]$} \\
\hline Chlorella vulgaris & Methylene blue & $100,-,-,-,-$ & 83.04 & {$[57]$} \\
\hline Ulva lactuca & Methylene blue & $25,10,-,-, 2.5$ & 4.012 & {$[58]$} \\
\hline Sargassum sp. & Acid Black 1 & $40,4.2,0.5,-,-$ & 96.8 & [59] \\
\hline $\begin{array}{l}\text { Oedogonium subplagiostomum } \\
\text { AP1 }\end{array}$ & Methyl orange & $500,6.5,132,-, 0.4$ & 97 & {$[60]$} \\
\hline Sargassum crassifolium & Malachite green & $5,8,2.5,25,2$ & 98.3 & {$[61]$} \\
\hline Chlorella vulgaris & Yellow dye & $10,-, 336,-,-$ & 3.12 & {$[17]$} \\
\hline Sphaerocystis schroeteri & Yellow dye & $10,-, 336,-,-$ & 45.03 & \\
\hline Cosmarium sp. & Malachite green & $10,9,-,-,-$ & 87.1 & {$[62]$} \\
\hline Desmodesmus sp. & $\begin{array}{l}\text { Methylene blue } \\
\text { Malachite green }\end{array}$ & $20,-, 144,-,-$ & 98.6 & {$[63]$} \\
\hline $\begin{array}{l}\text { Spirogyra sp. (CKW1) and } \\
\text { Cladophora sp. (PKS33) }\end{array}$ & Reactive blue azo dyes & $100,7,168,30,-$ & & {$[64]$} \\
\hline \multirow{2}{*}{ Spirulina platensis } & Acid Black 210 & $125,2,1,60,0.5$ & 98.55 & \multirow{2}{*}[65]{} \\
\hline & Acid Blue 7 & $125,2,1.25,60,0.5$ & 97.05 & \\
\hline \multirow{3}{*}{ Chlorella vulgaris } & Reactive Black 5 & $200,5,240,40,-$ & 80 & \multirow{3}{*}{ [66] } \\
\hline & Direct Blue 71 & $200,8,240,40,-$ & 78 & \\
\hline & Disperse Red 1 & $300,8,240,40,-$ & 84 & \\
\hline \multirow{3}{*}{ Oscillatoria sp. } & Malachite green & $5,-, 120,-, 0.2$ & 93 & \multirow{3}{*}[67]{} \\
\hline & Methylene blue & $5,-, 120,-, 0.2$ & 66 & \\
\hline & Safranin & $5,-, 120,-, 0.2$ & 52 & \\
\hline Nostoc sp. & Malachite green & $100,5,-, 50,-$ & 97.13 & {$[54]$} \\
\hline Ulva lactuca & $\begin{array}{l}\text { Methylene blue } \\
\text { Malachite green }\end{array}$ & $100,6,1,-, 0.1$ & $\begin{array}{l}67 \\
78\end{array}$ & {$[35]$} \\
\hline Ulva lactuca & Methylene blue & $25,8,2.83,-, 1.25$ & 91.92 & {$[4]$} \\
\hline Spirogyra sp. & Synazol & $-, 3,18,30,8$ & 85 & {$[68]$} \\
\hline Chlorella sp. & Malachite green & $-, 10,2.5,25,-$ & 80.7 & [69] \\
\hline Ulothrix sp. & Methylene blue & $90,7.9,0.5 .37,1$ & 86.1 & {$[70]$} \\
\hline Turbinaria conoides & Acid Blue 9 & $100,1,3.75,33,3$ & 87.64 & {$[71]$} \\
\hline Padina sanctae-crucis & Methyl violet & $10,8,1.33,25,2$ & 98.85 & {$[72]$} \\
\hline Chara sp. & Malachite green & $9.7,6.8,1.25,-, 3.9$ & 57.81 & {$[25]$} \\
\hline Scenedesmus quadricauda & Malachite green & $6,6,1.15,-, 0.004$ & 73.49 & \\
\hline Chlorella vulgaris & Malachite green & $6,6,1.15,-, 0.004$ & 91.61 & {$[73]$} \\
\hline Chlorella vulgaris & Congo red & $50,-, 216,35,-$ & 100 & [74] \\
\hline
\end{tabular}

5.3. Effect of Contact Time. The dye uptake rate of sorbent species is rapid at the beginning of the contact time; however, as the contact time reaches the equilibrium, the uptake rate is reduced or halted. For instance, in the study of Pratiwi et al. [4], the adsorption efficiency increased with a rise in contact time up to $110 \mathrm{~min}$ and later became less constant. There are a massive number of vacant surface sites which are accessible for sorption during the initial stage. Subsequently, the vacant surface sites are occupied, and it becomes hard to bind easily as a result of repulsive forces between the solute molecules on the solid and bulk phases [8].

5.4. Effect of Initial Concentration of Dyes. Dye concentration has a major influence on the dye abatement process. The adsorption efficiency is directly proportional to the pollutant concentration. Hence, the efficiency is generally found to be 
higher in lower dye concentration and subsequently reduced with an increment in dye concentration [88]. It is obvious that, as the adsorbent dose increases, the number of available adsorption sites increases; this, in turn, increases the uptake of the dye. For instance, according to Aravindhan et al. [86], the amount of uptake of Sandocryl Golden Yellow C-2G adsorbed by macroalga Caulerpa scalpelliformis increases from 4.86 to $33.15 \mathrm{mg} / \mathrm{g}$ for an increase in initial dye concentration from 25 to $200 \mathrm{mg} / \mathrm{L}$. Al Hamadi et al. [65] reported that the adsorption capacity of Acid Black 210 and Acid Blue 7 by Spirulina platensis was increased from $94.37 \%$ to $97.7 \%$ and $87.5 \%$ to $91.6 \%$, respectively, by increasing the initial dye concentration from 25 to $125 \mathrm{mg} / \mathrm{L}$.

5.5. Effect of Agitation Speed. Agitation is crucial for equal mixing of the medium components, dispersion of cells, and nutrients, as well as mass transfer phenomena in the dye abatement process. In addition to this, agitation also leads to shear force, which affects microbes in various dimensions that include morphological changes, rupture of the cell wall, variation in their growth, and product formation [8]. According to Doğar et al. [70], the increase of the mixing rate improves the transport of dye molecules from the bulk to the surface of the cell (film/boundary layer diffusion). In the study of Jerold and Sivasubramanian [89], an increment of agitation rate from 50 to $150 \mathrm{rpm}$ increased the uptake rate of malachite green from 21.5 to $56.2 \mathrm{mg} / \mathrm{g}$ by macroalga Sargassum swartzii.

5.6. Effect of Biomass Dosage. The dosage of the biosorbent (biomass concentration) is also another factor that influences the dye abatement capacity of biosorbents. There are direct relationships between biomass concentration and biosorption, which mean the number of biosorption sites increases with an increased dosage of biomass concentration that leads to efficient biosorption of dyes $[28,90]$. The study of Aravindhan et al. [86] reported that the amount of basic blue dye adsorbed by Caulerpa scalpelliformis was decreased from 54.16 to $19.58 \mathrm{mg} / \mathrm{g}$ with an increase in the concentration of seaweed biomass from 0.15 to $0.5 \mathrm{~g} / 50 \mathrm{~mL}$. According to Kumar et al. [91], cationic dye uptake by Pithophora sp. was decreased from $42.2 \mathrm{mg} / \mathrm{g}$ to $9.2 \mathrm{mg} / \mathrm{g}$ (57.8\% to $90.8 \%)$ with an increase in biomass concentration from $0.02 \mathrm{~g}$ to $0.06 \mathrm{~g}$. Therefore, it leads to an increment in the solute transfer rate onto the adsorbent surface, which means the amount of solute adsorbed onto the unit weight of adsorbent gets split with increasing biosorbent dosage [92].

\section{Mechanism of Dye Abatement by Algae}

Different microorganisms may have different pathways for degrading different dyes depending upon the dye structure, strategy of the microbial system for dye degradation, and many other factors. Even small structural differences can affect the decolorization process [85]. The way of microbial removal of dyes is generally adsorption or degradation [93]. Biosorption implies removing the dye molecules from the aqueous phase to the solid phase (the bioadsorbent), while biodegradation entails the enzymatic breakdown of the chemical bonds that constitute the chemical structure of the dyes [94]. Most studied algae that are involved in the decolorization and degradation of dyes are blue-green algae, green algae, and diatoms [36]. Algae biomass has the highest biosorption efficiency and electrostatic force of desirability for pollutants in wastewater due to its wide surface area and high binding ability. Several studies have shown that metabolites of pollutants found in wastewater are adsorbed by the algae surface [28].

Mechanisms of algal decolorization can involve enzymatic degradation, adsorption, or both. Color removal by algae is mainly due to three intrinsically different mechanisms such as assimilative utilization of chromophores for the production of algal biomass, $\mathrm{CO}_{2}$ and $\mathrm{H}_{2} \mathrm{O}$ transformation of colored molecules to noncolored ones, and adsorption of chromophores on algal biomass (Figure 2) $[21,28,95,96]$. Algae are capable of degrading azo dyes through an induced form of azoreductase. They promote the reductive cleavage of the azo bonds and release the aromatic amines that will be degraded in $\mathrm{CO}_{2}$ and $\mathrm{H}_{2} \mathrm{O}[33$, 97].

Algae have a high surface area and high binding affinity during biosorption that facilitate the biosorption capacity. The electrostatic attraction and complexation are known to take place during algal biosorption [94]. The functional groups found on the cell surface of algae are responsible for decolorization by attracting dye contaminants from the environments. The biosorption capacity of algae is mainly determined by the cell wall. The presence of the heteropolysaccharide and lipid compound on the cell wall of algae contains many functional groups such as amino, carboxyl, hydroxyl, and phosphate groups, which are responsible for causing strong attractive force between dyes and the cell wall [98]. Alginate has an important role in adsorption by brown algae through binding to pollutant ions. Generally, metal ions such as $\mathrm{K}^{+}, \mathrm{Na}^{+}, \mathrm{Ca}_{2}{ }^{+}$, and $\mathrm{Mg}^{2+}$, which are available on the algal biomass, are obtained from seawater which is bound to the acid functional groups [99].

\section{Functional Group Involvement during Dye Abatement by Algae}

Fourier-transform infrared (FTIR) spectroscopy will be used to determine the infrared spectrum of the major functional groups of the microbes. FTIR spectroscopy has the advantages of its simple, inexpensive, fast, noninvasive, and multiplex measurements. FTIR spectroscopy has already been used to study the biosorption of dyes from wastewaters using algae. The selected algal functional groups involved in the decolorization of different synthetic dyes are summarized in Table 4. According to the investigation of Foroutan et al. [100], Sargassum oligocystum has around six functional groups or active sites that adsorb (avoid toxicity) methylene blue and methyl violet. Similarly, the findings of Brahmbhatt and Jasrai [1] stated that Oscillatoria sp. and Spirogyra sp. have many active sites on their cell such as alcohol or phenol, alkynes, primary amines, chloroalkanes, and bromoalkanes for the blue dye decolorization process. Besides, other studies stated that the Oscillatoria sp. and Spirogyra sp. algal 


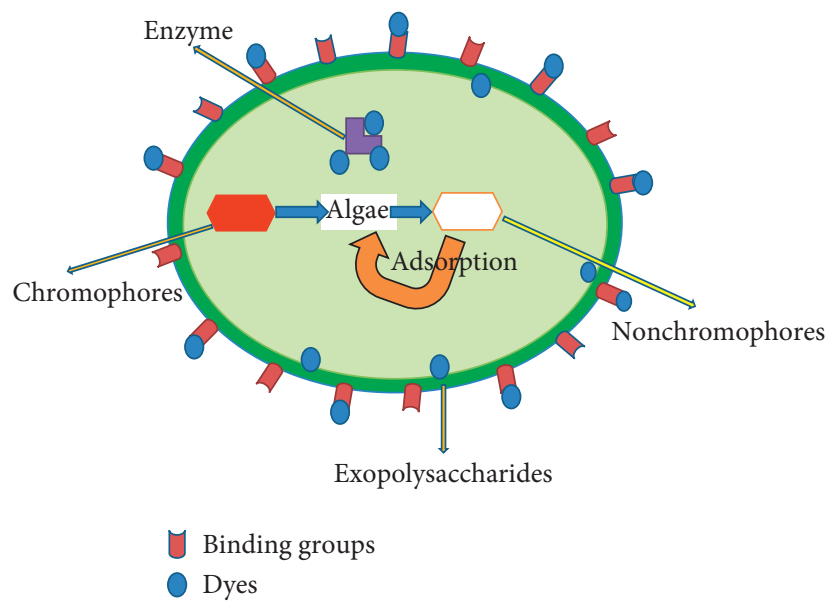

FIGURE 2: Mechanisms of dye adsorption by algae [28, 94].

TABLE 4: Algal functional group involved in decolorization of different synthetic dyes.

\begin{tabular}{|c|c|c|c|}
\hline Algae & Synthetic dyes & Functional groups involved & References \\
\hline Sargassum oligocystum & $\begin{array}{l}\text { Methylene blue } \\
\text { Methyl violet }\end{array}$ & $\mathrm{C}=\mathrm{C}, \mathrm{C}=\mathrm{O}, \mathrm{C}-\mathrm{H}, \mathrm{C}-\mathrm{O}, \mathrm{Fe}-\mathrm{O}$, and $\mathrm{C}-\mathrm{C}$ & {$[100]$} \\
\hline Oscillatoria sp. and Spirogyra & Blue dye & $\mathrm{OH}, \equiv \mathrm{C}-\mathrm{H}, \mathrm{N}-\mathrm{H}$, and $\mathrm{C}-\mathrm{X}(\mathrm{X}=\mathrm{Cl}, \mathrm{Br})$ & [1] \\
\hline sp. & Red dye & $\mathrm{OH}, \equiv \mathrm{C}-\mathrm{H}, \mathrm{N}-\mathrm{H}, \mathrm{C}=\mathrm{O}, \mathrm{C}-\mathrm{H}$, and $\mathrm{C}-\mathrm{X}(\mathrm{X}=\mathrm{Cl}, \mathrm{Br})$ & {$[1]$} \\
\hline Sargassum muticum & Methylene blue & $\mathrm{O}-\mathrm{H}-\mathrm{NH} 2, \mathrm{C}=\mathrm{O}$, and $\mathrm{C}-\mathrm{O}$ & [101] \\
\hline Phormidium animale & Remazol Black B & $\mathrm{C}-\mathrm{H}$ and $\mathrm{CH}_{3}$ & [102] \\
\hline $\begin{array}{l}\text { Oedogonium } \\
\text { subplagiostomum AP1 }\end{array}$ & Methyl orange & $\mathrm{O}-\mathrm{H}, \mathrm{N}-\mathrm{H}$, and $-\mathrm{N}=\mathrm{N}-$ & {$[60]$} \\
\hline Spirulina platensis & Reactive Red 120 & $\mathrm{O}-\mathrm{H}, \mathrm{NH}_{2}, \mathrm{CH}_{2}, \mathrm{C}-\mathrm{N}, \mathrm{P}-\mathrm{O}, \mathrm{S}-\mathrm{O}$, and C-H & [103] \\
\hline Spirulina platensis & Tartrazine and allura red & $\mathrm{O}-\mathrm{H}, \mathrm{NH}_{2}, \mathrm{CH}_{2}, \mathrm{C}=\mathrm{C},-\mathrm{S}-\mathrm{O},-\mathrm{P}-\mathrm{O}$, and $-\mathrm{CH}$ & [104] \\
\hline Durvillaea antarctica & Methylene blue & $\mathrm{O}-\mathrm{H}, \mathrm{C}-\mathrm{H}, \mathrm{C}=\mathrm{O},-\mathrm{C}=\mathrm{C}-$, and $-\mathrm{CH}_{3}$ & [105] \\
\hline Padina gymnospora & Methylene blue & $\mathrm{N}-\mathrm{H}, \mathrm{C}-\mathrm{H}, \mathrm{R}-\mathrm{N}=\mathrm{C}=\mathrm{S}, \mathrm{C}=\mathrm{C}$, and $\mathrm{S}-\mathrm{S}$ & [106] \\
\hline Chlamydomonas variabilis & Methylene blue & $-\mathrm{OH},-\mathrm{NH}, \mathrm{C}-\mathrm{H}, \mathrm{HC}=\mathrm{O}$, and $\mathrm{R}_{2} \mathrm{C}=\mathrm{O}$ & [107] \\
\hline Ulva lactuca & Malachite green & $-\mathrm{OH},-\mathrm{NH}, \mathrm{CH},-\mathrm{COO}-,-\mathrm{SO}_{3}$, and $-\mathrm{C}-\mathrm{O}$ & \\
\hline Sargassum crassifolium & Malachite green & $-\mathrm{OH},-\mathrm{NH}, \mathrm{CH},-\mathrm{COO}-,-\mathrm{SO}_{3},-\mathrm{C}-\mathrm{O}$, and $-\mathrm{C}=\mathrm{O}$ & {$[61]$} \\
\hline Gracilaria corticata & Malachite green & $\mathrm{OH},-\mathrm{NH}, \mathrm{CH},-\mathrm{SO}_{3},-\mathrm{C}-\mathrm{O}$, and $-\mathrm{C}=\mathrm{O}$ & \\
\hline Dictyota cervicornis & Methylene blue & $\begin{array}{c}\mathrm{N}-\mathrm{H}, \mathrm{O}-\mathrm{H},-\mathrm{CH}, \mathrm{C}-\mathrm{CH}_{3}, \mathrm{C}=\mathrm{O}, \mathrm{C}-\mathrm{OH}, \mathrm{P}-\mathrm{O}-\mathrm{C}, \mathrm{S} \mathrm{O} \text {, and } \\
\mathrm{C}-\mathrm{S}-\mathrm{O}\end{array}$ & [99] \\
\hline Caulerpa scalpelliformis & Sandocryl Golden Yellow C-2G & $-\mathrm{OH},-\mathrm{COOH}, \mathrm{C}=\mathrm{O}$, and $\mathrm{C}-\mathrm{O}$ & {$[86]$} \\
\hline Kappaphycus alvarezii & Rhodamine B & $\begin{array}{c}\mathrm{N}-\mathrm{H}, \mathrm{H}-\mathrm{O} / \mathrm{N}, \mathrm{COO}^{-}, \mathrm{C}=\mathrm{N}, \mathrm{C}-\mathrm{O}-\mathrm{C}, \mathrm{N}-\mathrm{O},-\mathrm{OH}, \mathrm{C}-\mathrm{H}, \mathrm{C}=\mathrm{O}, \\
\mathrm{C}=\mathrm{C}, \mathrm{C}-\mathrm{N}, \mathrm{C}-\mathrm{O} \text {, and } \mathrm{C}-\mathrm{Cl}\end{array}$ & \\
\hline Gracilaria salicornia & Rhodamine B & $\begin{array}{c}\mathrm{N}-\mathrm{H}, \mathrm{H}-\mathrm{O} / \mathrm{N}, \mathrm{COO}^{-}, \mathrm{C}=\mathrm{N}, \mathrm{C}-\mathrm{O}-\mathrm{C}, \mathrm{N}-\mathrm{O},-\mathrm{OH}, \mathrm{C}-\mathrm{H}, \mathrm{C}=\mathrm{O}, \\
\mathrm{C}=\mathrm{C}, \mathrm{C}-\mathrm{N}, \mathrm{C}-\mathrm{O} \text {, and } \mathrm{C}-\mathrm{Cl}\end{array}$ & {$[90]$} \\
\hline Gracilaria edulis & Rhodamine B & $\begin{array}{c}\mathrm{N}-\mathrm{H}, \mathrm{H}-\mathrm{O} / \mathrm{N}, \mathrm{COO}^{-}, \mathrm{C}=\mathrm{N}, \mathrm{C}-\mathrm{O}-\mathrm{C}, \mathrm{N}-\mathrm{O},-\mathrm{OH}, \mathrm{C}-\mathrm{H}, \mathrm{C}=\mathrm{O}, \\
\mathrm{C}=\mathrm{C}, \mathrm{C}-\mathrm{N}, \mathrm{C}-\mathrm{O} \text {, and } \mathrm{C}-\mathrm{Cl}\end{array}$ & \\
\hline Enteromorpha prolifera & Direct Fast Scarlet 4BS & $\mathrm{O}-\mathrm{H}, \mathrm{N}-\mathrm{H},-\mathrm{SO}_{3}, \mathrm{C}=\mathrm{O}, \mathrm{C}-\mathrm{N}$, and $\mathrm{PO}_{4}$ & {$[84]$} \\
\hline Brown algae & Crystal violet & $\mathrm{O}-\mathrm{H}, \mathrm{N}-\mathrm{H}, \mathrm{C}-\mathrm{H}, \mathrm{C}=\mathrm{O}, \mathrm{C}-\mathrm{OH}, \mathrm{O}-\mathrm{C}-\mathrm{O}$, and $-\mathrm{C}-\mathrm{O}$ & [108] \\
\hline Fucus vesiculosus & Methylene blue & $\mathrm{O}-\mathrm{H}, \mathrm{C}-\mathrm{H}, \mathrm{C}=\mathrm{O}, \mathrm{N}-\mathrm{H}$, and $\mathrm{C}-\mathrm{O}$ & \\
\hline Spirulina maxima & Methylene blue & $\mathrm{O}-\mathrm{H}, \mathrm{C}-\mathrm{H}, \mathrm{C}=\mathrm{O}, \mathrm{N}-\mathrm{H}$, and $\mathrm{C}-\mathrm{O}$ & [109] \\
\hline Chlorella pyrenoidosa & Methylene blue & $\mathrm{O}-\mathrm{H}, \mathrm{C}-\mathrm{H}, \mathrm{C}=\mathrm{O}, \mathrm{N}-\mathrm{H}$, and $\mathrm{C}-\mathrm{O}$ & \\
\hline Laminaria japonica & Methylene blue & $-\mathrm{OH},-\mathrm{NH},-\mathrm{CH}_{2},-\mathrm{CH}_{3}, \mathrm{C}=\mathrm{O}, \mathrm{C}-\mathrm{O},-\mathrm{COOH}$, and $\mathrm{C}-\mathrm{O}-\mathrm{C}$ & {$[110]$} \\
\hline Spirulina algae & Direct Yellow 12 & $\mathrm{OH}, \mathrm{C}=\mathrm{C}, \mathrm{C}-\mathrm{H}$, and $\mathrm{C}=\mathrm{C}$ & {$[111]$} \\
\hline Padina sanctae-crucis & Methyl violet & $-\mathrm{OH},-\mathrm{NH}_{2},-\mathrm{C}-\mathrm{H},-\mathrm{C}=\mathrm{O}, \mathrm{C}-\mathrm{O},-\mathrm{C}-\mathrm{N}-\mathrm{C}$, and $\mathrm{S}=\mathrm{O}$ & {$[72]$} \\
\hline Chaetophora elegans & Methylene blue & $-\mathrm{OH},-\mathrm{NH} 2,-\mathrm{CH}, \mathrm{COOH},>\mathrm{C}=\mathrm{O}, \mathrm{C}-\mathrm{O},>\mathrm{S}=\mathrm{O}$, and $\mathrm{C}-\mathrm{N}$ & [112] \\
\hline Chara sp. & Malachite green & $\mathrm{C}=\mathrm{C}, \mathrm{C}-\mathrm{N}, \mathrm{C}-\mathrm{H},-\mathrm{CH}_{3}$, and $-\mathrm{C}-\mathrm{N}-$ & {$[25]$} \\
\hline Scenedesmus quadricauda & Malachite green & $-\mathrm{OH},-\mathrm{NH}$, and $\mathrm{COOH}$ & \\
\hline Chlorella vulgaris & Malachite green & $-\mathrm{OH},-\mathrm{NH}$, and $\mathrm{COOH}$ & [73] \\
\hline Sargassum swartzii & Malachite green & $\mathrm{NH}_{2}, \mathrm{C}=\mathrm{O}, \mathrm{C}-\mathrm{O}, \mathrm{C}-\mathrm{O}$, and $\mathrm{C}-\mathrm{H}$ & [89] \\
\hline Laminaria japonica & Malachite green & $-\mathrm{OH},-\mathrm{NH}, \mathrm{C}-\mathrm{H}, \mathrm{C}=\mathrm{O}$, and $\mathrm{C}-\mathrm{O}$ & [113] \\
\hline
\end{tabular}


TABLE 4: Continued.

\begin{tabular}{|c|c|c|c|}
\hline Algae & Synthetic dyes & Functional groups involved & References \\
\hline Nostoc comminutum & $\begin{array}{c}\text { Remazol Black } 5 \text { and Remazol } \\
\text { Brilliant Blue }\end{array}$ & $-\mathrm{OH},-\mathrm{NH},-\mathrm{C}=\mathrm{O}, \mathrm{N}-\mathrm{H},-\mathrm{C}-\mathrm{O}$, and $-\mathrm{C}-\mathrm{N}$ & {$[114]$} \\
\hline Nostoc carneum & Methyl orange & $\begin{array}{c}\mathrm{C}-\mathrm{H},=\mathrm{C}-\mathrm{H}, \mathrm{C}=\mathrm{O}, \mathrm{C}=\mathrm{C}, \mathrm{NO}_{2}, \mathrm{P}-\mathrm{OH}, \mathrm{S}=\mathrm{O}, \mathrm{O}-\mathrm{H}, \mathrm{N}-\mathrm{H}, \mathrm{P}-\mathrm{O}, \\
\text { and } \mathrm{C}-\mathrm{S}\end{array}$ & [115] \\
\hline Vaucheria sp. & Malachite green & $\mathrm{C}=\mathrm{C}, \mathrm{C}-\mathrm{N}, \mathrm{C}-\mathrm{H}$, and $-\mathrm{CH} 3$ & {$[25]$} \\
\hline
\end{tabular}

cell have functional groups that encompass alcohol, phenol, terminal alkynes, primary amines, ketone, vinyl, chloroalkanes, and bromoalkanes for the red dye adsorption process [67, 68]. The investigation of Khataee et al. [25] illustrated that malachite green was adsorbed by the functional groups on Vaucheria sp. such as methyl, terminal alkynes, $\mathrm{C}=\mathrm{C}$, and $\mathrm{C}-\mathrm{N}$.

\section{Conclusion}

The use of dyes is increasing day by day due to their multiple applications in different industries. The discharge of dyes into the environment not only produces an aesthetically unpleasing effect but also creates serious environmental concerns. Remediation of dye-contaminated wastewater by phycoremediation technology has gained much emphasis in recent years. Accordingly, phycoremediation technology plays a vital role principally in developing and underdeveloped countries due to the advantages such as ease of availability, high efficiency, cost effectiveness, large specific surface area, environmentally friendly, and chemical and physical stability. Algae have different functional groups on their cell wall such as amino, carboxyl, hydroxyl, and phosphate groups, which are responsible for the dye removal process. Various operational conditions such as solution $\mathrm{pH}$, contact time, initial dye concentration, adsorbent dosage, and temperature are the crucial elements for the removal of dyes. Hence, these factors are taken under consideration during evaluating the performance of algal capacity regarding that of dye abatement. Despite the progressive developments in alga-based removal technologies, considerable limitations still exist which demand future research for the utilization of holistic phycoremediation removal techniques in an effective manner on a large scale.

\section{Conflicts of Interest}

The authors declare that they have no conflicts of interest.

\section{Acknowledgments}

The authors wish to acknowledge all who had been instrumental in the creation of this review article.

\section{References}

[1] H. N. Brahmbhatt and T. R. Jasrai, "The role of algae in bioremediation of textile effluent," International Journal of Engineering Research and General Science, vol. 4, pp. 20912730, 2016.

[2] F. D. Chequer, G. R. De Oliveira, E. A. Ferraz, J. C. Cardoso, M. B. Zanoni, and D. P. de Oliveira, "Textile dyes: dyeing process and environmental impact," Eco-friendly Textile Dyeing and Finishing, vol. 6, no. 6, pp. 151-176, 2013.

[3] K. S. Bharathi and S. T. Ramesh, "Removal of dyes using agricultural waste as low-cost adsorbents: a review," Applied Water Science, vol. 3, no. 4, pp. 773-790, 2013.

[4] D. Pratiwi, D. J. Prasetyo, and C. D. Poeloengasih, “Adsorption of methylene blue dye using marine algae Ulva lactuca," IOP Conference Series: Earth and Environmental Science, vol. 251, no. 1, p. 012012, 2019.

[5] O. J. Hao, H. Kim, and P.-c. Chang, "Decolourization of wastewater. Critical reviews," Journal of Environmental Science and. Technology, vol. 30, pp. 449-505, 2000.

[6] M. A. Hassaan, A. El Nemr, and A. Hassaan, "Health and environmental impacts of dyes: mini review," American Journal of Environmental Science and Engineering, vol. 1, no. 3, pp. 64-67, 2017.

[7] H. Y. El-Kassas and L. A. Mohamed, "Bioremediation of the textile waste effluent by Chlorella vulgaris," The Egyptian Journal of Aquatic Research, vol. 40, no. 3, pp. 301-308, 2014.

[8] M. Alaguprathana and M. Poonkothai, "Bioremediation of textile dyeing effluent using algae-a review," Journal of Advances in Microbiology, vol. 7, no. 1, pp. 1-12, 2017.

[9] A. Admasu, Adsorptive Removal of Reactive Azo Dyes Using Industrial Residue, Addis Ababa University, Addis Ababa, Ethiopia, 2008, http://localhost:80/xmlui/handle/123456789/ 4041.

[10] A. Ahmad, S. H. Mohd-Setapar, C. S. Chuong et al., "Recent advances in new generation dye removal technologies: novel search for approaches to reprocess wastewater," RSC Advances, vol. 5, no. 39, pp. 30801-30818, 2015.

[11] T. Robinson, G. McMullan, R. Marchant, and P. Nigam, "Remediation of dyes in textile effluent: a critical review on current treatment technologies with a proposed alternative," Bioresource Technology, vol. 77, no. 3, pp. 247-255, 2001.

[12] K. D. Mojsov, D. Andronikov, A. Janevski, A. Kuzelov, and S. Gaber, "The application of enzymes for the removal of dyes from textile effluents," Advanced Technologies, vol. 5, no. 1, pp. 81-86, 2016.

[13] K. Singh and S. Arora, "Removal of synthetic textile dyes from wastewaters: a critical review on present treatment technologies," Critical Reviews in Environmental Science and Technology, vol. 41, no. 9, pp. 807-878, 2011.

[14] M. P. Shah, "Azo dye removal technologies," Advances in Research and Applications, vol. 5, no. 1, p. 1090, 2018.

[15] Textile Learners Report, Types of Dyes and Their Properties, https://textilelearners.com/types-of-dyes-and-theirproperties/, 2018.

[16] S. Lata and H. Kaur, "Isolation, characterization and optimization of azo dye degrading bacteria and its application in textile industry," International Journal, vol. 4, no. 5, pp. 1370-1376, 2016.

[17] E. S. Raymond and K. M. Omo, "Biodecolourization of yellow dye using chlorella vulgaris and sphaerocystics schroeteri," American Journal of Biological and Environmental Statistics, vol. 5, no. 1, pp. 1-6, 2019. 
[18] P. Jadhav and K. Tarfe, "Isolation of Methylene Blue dye degrading bacteria from effluent, screening and evaluation of their dye decolorization activity," International Journal of Scientific Development and Research, vol. 4, no. 8, pp. 224230, 2019.

[19] P. M. Dellamatrice, M. E. Silva-Stenico, L. A. B. D. Moraes, M. F. Fiore, and R. T. R. Monteiro, "Degradation of textile dyes by cyanobacteria," Brazilian Journal of Microbiology, vol. 48, no. 1, pp. 25-31, 2017.

[20] B. Legerská, D. Chmelová, and M. Ondrejovič, "Degradation of synthetic dyes by laccases-a mini-review," Nova Biotechnologica et Chimica, vol. 15, no. 1, pp. 90-106, 2016.

[21] A. Sharif, Z. Nasreen, R. Bashir, and S. Kalsoom, "Microbial degradation of textile industry effluents: a review," Pure and Applied Biology (PAB), vol. 9, no. 4, pp. 2361-2382, 2020.

[22] U. Tahir, A. Yasmin, and U. H. Khan, "Phytoremediation: potential flora for synthetic dyestuff metabolism," Journal of King Saud University-Science, vol. 28, no. 2, pp. 119-130, 2016.

[23] S. El Harfi and A. El Harfi, "Classifications, properties and applications of textile dyes: a review," Applied Journal of Environmental Engineering Science, vol. 3, no. 3, 2017.

[24] H. I. R. Zhao and H. M. Hwang, "Biodegradation of a model azo disperse dye by the white-rot fungus Pleurotus ostreatus," Journal of International Biodeterioration and Biodegradation, vol. 57, pp. 1-6, 2005.

[25] A. R. Khataee, G. Dehghan, E. Ebadi, and M. Pourhassan, "Central composite design optimization of biological dye removal in the presence of macroalgae Chara sp," CLEAN-Soil, Air, Water, vol. 38, no. 8, pp. 750-757, 2010.

[26] J. Axelsson, U. Nilsson, E. Terrazas, T. A. Aliaga, and U. Welander, "Decolorization of the textile dyes Reactive Red 2 and Reactive Blue 4 using Bjerkandera sp. Strain BOL 13 in a continuous rotating biological contactor reactor," Enzyme and Microbial Technology, vol. 39, no. 1, pp. 32-37, 2006.

[27] S. Asad, M. A. Amoozegar, A. Pourbabaee, M. N. Sarbolouki, and S. M. M. Dastgheib, "Decolorization of textile azo dyes by newly isolated halophilic and halotolerant bacteria," Bioresource Technology, vol. 98, no. 11, pp. 2082-2088, 2007.

[28] D. Bhatia, N. R. Sharma, J. Singh, and R. S. Kanwar, "Biological methods for textile dye removal from wastewater: a review," Critical Reviews in Environmental Science and Technology, vol. 47, no. 19, pp. 1836-1876, 2017.

[29] S. Benkhaya, S. M'rabet, and A. El Harfi, "Classifications, properties, recent synthesis and applications of azo dyes," Heliyon, vol. 6, no. 1, p. e03271, 2020.

[30] L. Robert, F. Joseph, and A. Alexander, Fisher's Contact Dermatitis in Textiles and Shoes, pp. 339-401, BC Decker Inc, Ontario, Canada, 2008.

[31] H. H. Omar, "Algal decolorization and degradation of monoazo and diazo dyes," Pakistan Journal of Biological Sciences, vol. 11, no. 10, pp. 1310-1316, 2008.

[32] R. D. Saini, "Textile organic dyes: polluting effects and elimination methods from textile waste water," International Journal of Chemical Engineering Research, vol. 9, no. 1, pp. 121-136, 2017.

[33] B. Lellis, C. Z. Fávaro-Polonio, J. A. Pamphile, and J. C. Polonio, "Effects of textile dyes on health and the environment and bioremediation potential of living organisms," Biotechnology Research and Innovation, vol. 3, no. 2, pp. 275-290, 2019.

[34] R. M. Moattari and T. Mohammadi, "Hybrid adsorbents for dye removal from wastewater," in Green Adsorbents to Remove Metals, Dyes and Boron from Polluted Water.
Environmental Chemistry for a Sustainable World, A. M. Inamuddin, E. Lichtfouse, and A. Asiri, Eds., Vol. 49, Springer, Berlin, Germany, 2021.

[35] R. Deokar and A. Sabale, "Biosorption of methylene blue and malachite green from binary solution onto Ulva Lactuca," International Journal of Current Microbiology and Applied Sciences, vol. 3, no. 5, pp. 295-304, 2014.

[36] P. K. Singh and R. L. Singh, "Bio-removal of azo dyes: a review," International Journal of Applied Sciences and Biotechnology, vol. 5, no. 2, pp. 108-126, 2017.

[37] S. Yu, M. Liu, M. Ma, M. Qi, Z. Lü, and C. Gao, "Impacts of membrane properties on reactive dye removal from dye/salt mixtures by asymmetric cellulose acetate and composite polyamide nanofiltration membranes," Journal of Membrane Science, vol. 350, no. 1-2, pp. 83-91, 2010.

[38] M. Yusuf, "Synthetic dyes: a threat to the environment and water ecosystem," In Textiles and Clothing, M. Shabbir Ed, Wiley, Hoboken, NJ, USA, pp. 11-26, 2019.

[39] P. Dwivedi and R. S. Tomar, "Bioremediation of textile effluent for degradation and decolourization of synthetic dyes: a review," International Journal of Current Research in Life Sciences, vol. 7, no. 4, pp. 1948-1951, 2018.

[40] Y. Kang, X. Xu, H. Pan, J. Tian, W. Tang, and S. Liu, "Decolorization of mordant yellow 1 using Aspergillus sp. TS-A CGMCC 12964 by biosorption and biodegradation," Bioengineered, vol. 9, no. 1, pp. 222-232, 2018.

[41] V. K. Gupta, S. Khamparia, I. Tyagi, D. Jaspal, and A. Malviya, "Decolorization of mixture of dyes: a critical review," Global Journal of Environmental Science and Management, vol. 1, no. 1, pp. 71-94, 2015.

[42] P. Kalyani, V. Hemalatha, K. Vineela, and K. P. J. Hemalatha, "Degradation of toxic dyes-a review," International Journal of Pure \& Applied Bioscience, vol. 4, no. 5, pp. 81-89, 2016.

[43] O. Türgay, G. Ersöz, S. Atalay, J. Forss, and U. Welander, "The treatment of azo dyes found in textile industry wastewater by anaerobic biological method and chemical oxidation," Separation and Purification Technology, vol. 79, no. 1, pp. 26-33, 2011.

[44] M. S. Podder and C. B. Majumder, "Phycoremediation potential of Botryococcus braunii: bioremediation and toxicity of as (III) and as (V)," Water Conservation Science and Engineering, vol. 1, no. 1, pp. 49-68, 2016.

[45] K. Preeti and S. Veena, "Bioremediation of textile dyes by using blue green algae," International Journal for Scientific Research \& Development, vol. 5, no. 3, pp. 1322-1324, 2017.

[46] W. T. Tsai and H. R. Chen, "Removal of malachite green from aqueous solution using low-cost chlorella-based biomass," Journal of Hazardous Materials, vol. 175, no. 1-3, pp. 844-849, 2010.

[47] M. Packer, "Algal capture of carbon dioxide; biomass generation as a tool for greenhouse gas mitigation with reference to New Zealand energy strategy and policy," Energy Policy, vol. 37, no. 9, pp. 3428-3437, 2009.

[48] H. D. Utomo, K. X. D. Tan, Z. Y. D. Choong, J. J. Yu, J. J. Ong, and Z. B. Lim, "Biosorption of heavy metal by algae biomass in surface water," Journal of Environmental Protection, vol. 7, no. 11, pp. 1547-1560, 2016.

[49] C. Lavanya, D. Rajesh, C. Sunil, and S. Sarita, "Degradation of toxic dyes: a review," International Journal of Current Microbiology and Applied Sciences, vol. 3, no. 6, pp. 189-199, 2014.

[50] N. Daneshvar, A. R. Khataee, M. H. Rasoulifard, and M. Pourhassan, "Biodegradation of dye solution containing Malachite Green: optimization of effective parameters using 
Taguchi method," Journal of Hazardous Materials, vol. 143, no. 1-2, pp. 214-219, 2007.

[51] F. A. Alseroury, "Simultaneous decolorization of dye contaminated wastewater and energy production using algae," Journal of Biochemical Technology, vol. 9, no. 4, p. 15, 2018.

[52] L. C. Arteaga, M. P. Zavaleta, W. M. Eustaquio, and J. M. Bobadilla, "Removal of aniline blue dye using live microalgae Chlorella vulgaris," Journal of Energy \& Environmental Sciences, vol. 2, no. 1, pp. 6-12, 2018.

[53] G. Boduroğlu, N. K. Kılıç, and G. Dönmez, "Bioremoval of reactive blue 220 by gonium sp. biomass," Environmental Technology, vol. 35, no. 19, pp. 2410-2415, 2014.

[54] S. M. Gajare and S. Menghani, "Biosorption of malachite green by naturally grown algal biomass from Girna river, Jalgaon District, Maharashtra," Journal of Algal Biomass Utilization, vol. 3, no. 4, pp. 60-65, 2012.

[55] J. H. Liu, L. Zhang, D. C. Zha, L. Q. Chen, X. X. Chen, and Z. M. Qi, "Biosorption of malachite green onto Haematococcus pluvialis observed through synchrotron Fouriertransform infrared microspectroscopy," Letters in Applied Microbiology, vol. 67, no. 4, pp. 348-353, 2018.

[56] E. Baldev, D. MubarakAli, A. Ilavarasi, D. Pandiaraj, K. S. S. Ishack, and N. Thajuddin, "Degradation of synthetic dye, Rhodamine B to environmentally non-toxic products using microalgae," Colloids and Surfaces B: Biointerfaces, vol. 105, pp. 207-214, 2013.

[57] J. Y. Chin, L. M. Chng, S. S. Leong, S. P. Yeap, N. H. M. Yasin, and P. Y. Toh, "Removal of synthetic Dye by Chlorella vulgaris microalgae as natural adsorbent," Arabian Journal for Science and Engineering, vol. 45, no. 9, pp. 7385-7395, 2020.

[58] A. El Sikaily, A. Khaled, A. E. Nemr, and O. Abdelwahab, "Removal of methylene blue from aqueous solution by marine green alga Ulva lactuca," Chemistry and Ecology, vol. 22, no. 2, pp. 149-157, 2006.

[59] G. Vijayaraghavan and S. Shanthakumar, "Effective removal of acid Black 1 dye in textile effluent using alginate from Brown algae as a coagulant," Iranian Journal of Chemistry and Chemical Engineering, vol. 37, no. 4, 2018.

[60] A. Maruthanayagam, P. Mani, K. Kaliappan, and S. Chinnappan, "In vitro and in silico studies on the removal of methyl orange from aqueous solution using Oedogonium subplagiostomum AP1," Water, Air, \& Soil Pollution, vol. 231, pp. 1-21, 2020.

[61] H. Omar, A. El-Gendy, and K. Al-Ahmary, "Bioremoval of toxic dye by using different marine macroalgae," Turkish Journal of Botany, vol. 42, no. 1, pp. 15-27, 2018.

[62] N. Daneshvar, M. Ayazloo, A. R. Khataee, and M. Pourhassan, "Biodegradation of the textile dye malachite green by Microalgae Cosmarium sp," International Journal for Science and High Technology and Environmental Sciences, vol. 1384, pp. 1-5, 2005.

[63] A. T. Al-Fawwaz and M. Abdullah, "Decolorization of methylene blue and malachite green by immobilized Desmodesmus sp. isolated from North Jordan," International Journal of Environmental Science and Development, vol. 7, no. 2, p. 95, 2016.

[64] R. Waqas, M. Arshad, H. N. Asghar, and M. Asghar, "Optimization of factors for enhanced phycoremediation of reactive blue azo dye," International Journal of Agriculture and Biology, vol. 17, no. 4, 2015.

[65] A. Al Hamadi, U. R. A. Z. Güven, H. Katircioğlu, and Ö. Osmanağaoğlu, "Adsorption of azo dyes from textile wastewater by Spirulina Platensis," Eurasian Journal of Environmental Research, vol. 1, no. 1, pp. 19-27, 2017.

[66] T. Ishchi and G. Sibi, "Azo dye degradation by Chlorella vulgaris: optimization and kinetics," International Journal of Biological Chemistry, vol. 14, no. 1, pp. 1-7, 2020.

[67] G. Gelebo, L. Tessema, K. Kehshin et al., "Phycoremediation of synthetic dyes in an aqueous solution using an indigenous Oscillatoria sp., from Ethiopia," Ethiopian Journal of Sciences and Sustainable Development, vol. 7, no. 2, pp. 14-20, 2020.

[68] M. A. Khalaf, "Biosorption of reactive dye from textile wastewater by non-viable biomass of Aspergillus niger and Spirogyra sp," Bioresource Technology, vol. 99, no. 14, pp. 6631-6634, 2008.

[69] N. Daneshvar, M. Ayazloo, A. R. Khataee, and M. Pourhassan, "Biological decolorization of dye solution containing Malachite Green by microalgae Cosmarium sp," Bioresource Technology, vol. 98, no. 6, pp. 1176-1182, 2007.

[70] Ç. Doğar, A. Gürses, M. Açıkyıldız, and E. Özkan, "Thermodynamics and kinetic studies of biosorption of a basic dye from aqueous solution using green algae Ulothrix sp," Colloids and Surfaces B: Biointerfaces, vol. 76, no. 1, pp. 279-285, 2010.

[71] R. Rajeshkannan, M. Rajasimman, and N. Rajamohan, "Optimization, equilibrium and kinetics studies on sorption of Acid Blue 9 using brown marine algae Turbinaria conoides," Biodegradation, vol. 21, no. 5, pp. 713-727, 2010.

[72] R. Mahini, H. Esmaeili, and R. Foroutan, "Adsorption of methyl violet from aqueous solution using brown algae Padina sanctae-crucis," Turkish Journal of Biochemistry, vol. 43, no. 6, 2018.

[73] M. Kousha, O. Farhadian, S. Dorafshan, N. M. Soofiani, and A. Bhatnagar, "Optimization of malachite green biosorption by green microalgae-Scenedesmus quadricauda and Chlorella vulgaris: application of response surface methodology," Journal of the Taiwan Institute of Chemical Engineers, vol. 44, no. 2, pp. 291-294, 2013.

[74] N. S. Naji and J. M. Salman, "Effect of temperature variation on the efficacy of Chlorella vulgaris in decolorization of Congo red from aqueous solutions," Biochemical and Cellular Archives, vol. 19, no. 2, pp. 4169-4174, 2019.

[75] P. Aiyar, D. Schaeme, M. García-Altares et al., "Antagonistic bacteria disrupt calcium homeostasis and immobilize algal cells," Nature Communications, vol. 8, no. 1, pp. 1-13, 2017.

[76] K. S. Kumar, H. U. Dahms, E. J. Won, J. S. Lee, and K. H. Shin, "Microalgae-A promising tool for heavy metal remediation," Ecotoxicology and Environmental Safety, vol. 113, pp. 329-352, 2015.

[77] A. Suresh, A. Ayele, and S. Benor, "Isolation and morphological identification of some indigenous microalgae from Ethiopia for phycoprospecting," Ethiopian Journal of Sciences and Sustainable Development, vol. 6, no. 2, pp. 56-60, 2019.

[78] P. I. Macreadie, J. Jarvis, S. M. Trevathan-Tackett, and A. Bellgrove, "Seagrasses and macroalgae: importance, vulnerability and impacts," Climate Change Impacts on Fisheries and Aquaculture: A Global Analysis, Wiley-Blackwell, Hoboken, NJ, USA, pp. 729-770, 2017.

[79] B. Salehi, J. Sharifi-Rad, A. Seca et al., "Current trends on seaweeds: looking at chemical composition, phytopharmacology, and cosmetic applications," Molecules (Basel, Switzerland), vol. 24, no. 22, p. 4182, 2019.

[80] A. Gomez-Zavaglia, M. A. Prieto Lage, C. Jimenez-Lopez, J. C. Mejuto, and J. Simal-Gandara, "The potential of seaweeds as a source of functional ingredients of prebiotic and 
antioxidant value," Antioxidants (Basel, Switzerland), vol. 8, no. 9, p. 406, 2019.

[81] M. Takagi, K. Watanabe, K. Yamaberi, and T. Yoshida, "Limited feeding of potassium nitrate for intracellular lipid and triglyceride accumulation of Nannochloris sp. UTEX LB1999," Applied Microbiology and Biotechnology, vol. 54, no. 1, pp. 112-117, 2000.

[82] J. Paul, K. P. Rawat, K. S. S. Sarma, and S. Sabharwal, "Decoloration and degradation of Reactive Red-120 dye by electron beam irradiation in aqueous solution," Applied Radiation and Isotopes, vol. 69, no. 7, pp. 982-987, 2011.

[83] N. E. El-Naggar, R. A. Hamouda, I. E. Mousa, M. S. AbdelHamid, and N. H. Rabei, "Biosorption optimization, characterization, immobilization and application of Gelidium amansii biomass for complete $\mathrm{Pb}^{2+}$ removal from aqueous solutions," Scientific Reports, vol. 8, no. 1, p. 13456, 2018.

[84] W. Sun, W. Sun, and Y. Wang, "Biosorption of Direct Fast Scarlet 4BS from aqueous solution using the green-tidecausing marine algae Enteromorpha prolifera," Spectrochimica Acta Part A: Molecular and Biomolecular Spectroscopy, vol. 223, Article ID 117347, 2019.

[85] H. Ali, "Biodegradation of synthetic dyes-a review," Water, Air, \& Soil Pollution, vol. 213, no. 1, pp. 251-273, 2010.

[86] R. Aravindhan, J. R. Rao, and B. U. Nair, "Kinetic and equilibrium studies on biosorption of basic blue dye by green macroalgae Caulerpa scalpelliformis," Journal of Environmental Science and Health Part A, vol. 42, no. 5, pp. 621-631, 2007.

[87] S. Yusra and H. N. Bhatti, "Factors affecting biosorption of direct dyes from aqueous solution," Asian Journal of Chemistry, vol. 22, no. 9, pp. 6625-6639, 2010.

[88] A. Maleki, A. H. Mahvi, R. Ebrahimi, and Y. Zandsalimi, "Study of photochemical and sonochemical processes efficiency for degradation of dyes in aqueous solution," Korean Journal of Chemical Engineering, vol. 27, no. 6, pp. 18051810, 2010.

[89] M. Jerold and V. Sivasubramanian, "Biosorption of malachite green from aqueous solution using brown marine macro algae Sargassum swartzii," Desalination and Water Treatment, vol. 57, no. 52, pp. 25288-25300, 2016.

[90] A. Selvakumar and S. Rangabhashiyam, "Biosorption of Rhodamine B onto novel biosorbents from Kappaphycus alvarezii, Gracilaria salicornia and Gracilaria edulis," Environmental Pollution, vol. 255, Article ID 113291, 2019.

[91] K. V. Kumar, V. Ramamurthi, and S. Sivanesan, "Biosorption of malachite green, a cationic dye onto Pithophora sp., a fresh water algae," Dyes and Pigments, vol. 69, no. 1-2, pp. 102-107, 2006.

[92] S. S. Phugare, D. C. Kalyani, S. N. Surwase, and J. P. Jadhav, "Ecofriendly degradation, decolorization and detoxification of textile effluent by a developed bacterial consortium," Ecotoxicology and Environmental Safety, vol. 74, no. 5, pp. 1288-1296, 2011.

[93] W. Tang, X. Xu, B. C. Ye, P. Cao, and A. Ali, "Decolorization and degradation analysis of Disperse Red $3 \mathrm{~B}$ by a consortium of the fungus Aspergillus sp. XJ-2 and the microalgae Chlorella sorokiniana XJK," RSC Advances, vol. 9, no. 25, pp. 14558-14566, 2019.

[94] H. Zohoorian, H. Ahmadzadeh, M. Molazadeh, M. Shourian, and S. Lyon, "Microalgal bioremediation of heavy metals and dyes," in Handbook of Algal Science, Technology and Medicine, O. Konur, Ed., pp. 659-674, Academic Press, Cambridge, MA, 2020.
[95] R. Khan, P. Bhawana, and M. H. Fulekar, "Microbial decolorization and degradation of synthetic dyes: a review," Reviews in Environmental Science and Bio/Technology, vol. 12, no. 1, pp. 75-97, 2013.

[96] S. Murugesan, M. C. Sridharan, and M. Yoganandam, "Biological decolorization and removal of metal from dye industry effluent by microalgae," Biosciences Biotechnology Research Asia, vol. 6, no. 1, pp. 111-120, 2016.

[97] R. Jamee and R. Siddique, "Biodegradation of synthetic dyes of textile effluent by microorganisms: an environmentally and economically sustainable approach," European Journal of Microbiology and Immunology, vol. 9, no. 4, pp. 114-118, 2019.

[98] D. Charumathi and N. Das, "Packed bed column studies for the removal of synthetic dyes from textile wastewater using immobilised dead C. tropicalis," Desalination, vol. 285, pp. 22-30, 2012.

[99] S. Khorvash and S. Behnam, "Removal of methylene blue dye by immobilized mixture of brown alga Dictyota cervicornis and activated carbon," Desalination and Water Treatment, vol. 162, pp. 383-390, 2019.

[100] R. Foroutan, R. Mohammadi, J. Razeghi, and B. Ramavandi, "Performance of algal activated carbon/Fe3O4 magnetic composite for cationic dyes removal from aqueous solutions," Algal Research, vol. 40, p. 101509, 2019.

[101] S. El Atouani, Z. Belattmania, A. Reani et al., "Brown seaweed Sargassum muticum as low-cost biosorbent of methylene blue," International Journal of Environmental Research, vol. 13, no. 1, pp. 131-142, 2019.

[102] G. Bayazıt, B. E. Tastan, and Ü. D. Gül, "Biosorption, isotherm and kinetic properties of common textile dye by Phormidium animale," Global Nest Journal, vol. 21, pp. 1-7, 2019.

[103] N. F. Cardoso, E. C. Lima, B. Royer et al., "Comparison of Spirulina platensis microalgae and commercial activated carbon as adsorbents for the removal of Reactive Red 120 dye from aqueous effluents," Journal of Hazardous Materials, vol. 241, pp. 146-153, 2012.

[104] G. L. Dotto, M. L. G. Vieira, V. M. Esquerdo, and L. A. D. A. Pinto, "Equilibrium and thermodynamics of azo dyes biosorption onto Spirulina platensis," Brazilian Journal of Chemical Engineering, vol. 30, no. 1, pp. 13-21, 2013.

[105] J. R. Guarin, J. C. Moreno-Pirajan, and L. Giraldo, "Kinetic study of the bioadsorption of methylene blue on the surface of the biomass obtained from the Algae D. antarctica," Journal of Chemistry, vol. 2018, Article ID 2124845, 12 pages, 2018.

[106] M. K. Faisal, P. Saranya, L. Prameela, and S. Renganthan, "Studies on adsorption potential of oil-extracted marine macro algae Padina gymnospora for the removal of methylene blue," International Journal of Environment and Sustainable Development, vol. 15, no. 3, pp. 272-285, 2016.

[107] R. M. Moghazy, "Activated biomass of the green microalga Chlamydomonas variabilis as an efficient biosorbent to remove methylene blue dye from aqueous solutions," Water $S A$, vol. 45, no. 1, pp. 20-28, 2019.

[108] A. Essekri, A. Hsini, Y. Naciri, M. Laabd et al., "Novel citric acid-functionalized brown algae with a high removal efficiency of crystal violet dye from colored wastewaters: insights into equilibrium, adsorption mechanism, and reusability," International Journal of Phytoremediation, vol. 23, no. 4, pp. 336-346, 2020.

[109] Y. A. R. Lebron, V. R. Moreira, and L. V. S. Santos, "Studies on dye biosorption enhancement by chemically modified 
Fucus vesiculosus, Spirulina maxima and Chlorella pyrenoidosa algae," Journal of Cleaner Production, vol. 240, Article ID 118197, 2019.

[110] H. Shao, Y. Li, L. Zheng, T. Chen, and J. Liu, "Removal of methylene blue by chemically modified defatted brown algae Laminaria japonica," Journal of the Taiwan Institute of Chemical Engineers, vol. 80, pp. 525-532, 2017.

[111] M. H. Marzbali, A. A. Mir, M. Pazoki, R. Pourjamshidian, and M. Tabeshnia, "Removal of direct yellow 12 from aqueous solution by adsorption onto spirulina algae as a high-efficiency adsorbent," Journal of Environmental Chemical Engineering, vol. 5, no. 2, pp. 1946-1956, 2017.

[112] M. M. El Jamal and M. C. Ncibi, "Biosorption of methylene blue by Chaetophora elegans algae: kinetics, equilibrium and thermodynamic studies," Acta Chimica Slovenica, vol. 59, no. 1, pp. 24-31, 2012.

[113] X. S. Wang, Y. Zhou, and Y. Jiang, "Evaluation of marine brown Laminaria japonica algae as a low-cost adsorbent for the removal of malachite green dye from aqueous solution," Adsorption Science \& Technology, vol. 27, no. 6, pp. 537-547, 2009.

[114] V. K. Gupta, R. Bhushan, A. Nayak, P. Singh, and B. Bhushan, "Biosorption and reuse potential of a blue green alga for the removal of hazardous reactive dyes from aqueous solutions," Bioremediation Journal, vol. 18, no. 3, pp. 179-191, 2014.

[115] M. H. Hussein, G. S. Abou El-Wafa, S. A. Shaaban-Dessuki, and R. M. El-Morsy, "Bioremediation of methyl orange onto Nostoc carneum biomass by adsorption, kinetics and isotherm studies," Global Advanced Research Journal of Microbiology, vol. 7, no. 1, pp. 6-22, 2018. 